\title{
PENGARUH KEMAMPUAN PEDAGOGIK DAN PERAN GURU SEBAGAI INSAN MULTIDIMENSI
}

\author{
Nadya Pratiwi (0142S1A018009) \\ Sekolah Tinggi Keguruan dan Ilmu Pendidikan Muhammadiyah Bogor \\ E-Mail: Nadyapratiwi994@gmail.com
}

\begin{abstract}
ABSTRAK
Guru adalah orang yang mempunya peranan penting dalam menumbuhkan dan mengembangkan potensi yang dimiliki siswanya. Peran guru disekolah sangatlah strategis, oleh karena itu guru dituntut untuk memiliki empat kompetensi sesuai standard kompetensi yang tertuang dalam Undang-undang Nomor 14 Tahun 2005 tentang Guru dan Dosen pada Bab IV Pasal 10 ayat (1), yang menyatakan bahwa "Kompetensi guru meliputi kompetensi pedagogik, kompetensi kepribadian, kompetensi sosial, dan kompetensi profesional yang diperoleh melalui pendidikan profesi.

Guru merupakan faktor yang sangat dominan dan penting dalam pendidikan formal pada umumnya, karena bagi peserta didik guru sering dijadikan tokoh teladan bahkan menjadi tokoh identifikasi diri. Oleh karena itu guru seyogyanya memiliki perilaku dan kompetensi yang memadai untuk mengembangkan peserta didik secara utuh. Untuk menguasai berbagai hal terutama kompetensi kepribadian, sosial dan profesional.
\end{abstract}




\section{PENGARUH KEMAMPUAN PEDAGOGIK DAN PERAN GURU SEBAGAI INSAN MULTIDIMENSI}

\section{A. Pengertian Metode pembelajaran}

Metode pembelajaran adalah proses penyampaian materi yang disampaikan oleh guru yang dilakukan secara sistematis dan teratur kepada pepserta didik. Seorang guru harus menerapkan metode yang tepat untuk kegiatan belajar mengajar sesuai dengan karakter para siswanya. Dengan begitu proses belajar mengajar dapat lebih menyenangkan dan siswa dapat menyerap pembelajaran yang disampaikan dengan mudah. Adapun bisa dikatakan metode pembalajaran ialah strategi atau taktik dalam melaksanakan kegiatan belajar mengajar dikelas yang di aplikasikan guru tercapai sesuai dengan tujuan yang telah ditetapkan.

Dalam dunia pendidikan, guru memegang peranan penting dan strategis.Sebagai pengajar, pendidik, pelatih para peserta didik, guru merupakan agen perubahan sosial (agent of social change) yang mengubah pola pikir, sikap dan perilaku umat manusia menuju kehidupan yang lebih baik, lebih bermartabat dan lebih mandiri (Sulfemi, 2016 : 52-70). Dalam kegiatan belajar-mengajar, guru tidak harus terpaku menggunakan satu metode, tetapi guru sebaiknya menggunakan metode yang bervariasi agar jalannya pengajaran tidak pemmembosankan. Penggunaan metode yang bervariasi tidak akan menguntungkan kegiatan belajar, bila penggunaannya tidak tepat, sesuai dengan situasi yang mendukungnya, serta kondisi psikologis peserta didik.

Tugas guru dalam pembelajaran adalah menjadikan peserta didik belajar melalui penciptaan strategi dan lingkungan belajar yang menarik dan bermakna. Pembelajaran dapat dikatakan berhasil apabila peserta didik dapat menerima dan menguasai materi dengan baik. (Sulfemi dan Minati, 2018 ; 228- 242).

\section{B. Konsep Pembelajaran}

Pembelajaran identik dengan pengajaran, suatu kegiatan di mana guru mengajar atau membimbing anak-anak menuju proses pendewasaan diri. jadi istilah pembelajaran setara dengan istilah teaching dan instruction. Artinya, kita tidak harus secara diametral memepertentangkan antara pengajaran (teacher-centered) dengan pembelajaran (student centered), karena pada hakikatnya kedua kegiatan itu dapat berlangsung sinergis. Dengan demikian, disini juga harus dimaknai bahwa dalam pengajaran guru belajar, sedangkan dalam belajar juga mengajar. 
Kompetensi pedagogik merupakan kemampuan guru dalam pengelolaan pembelajaran peserta didik yang sekurang-kurangnya meliputi:

1) Pemahaman wawasan atau landasan kependidikan

2) Pemahaman terhadap peserta didik

3) Pengembangan kurikulum atau silabus

4) Perancangan pembelajaran

5) Pelaksanaan pembelajaran yang mendidik dan dialogis

6) Teknologi pembelajaran

7) Evaluasi hasil belajar

8) Pengembangan peserta didik untuk mengaktualisasikan berbagai proses yang dimilikinya.

Guru yang berkompetensi pedagogik baik akan dapat memunculkan motivasi peserta didik dalam mengikuti pelajaran. Kompetensi Pedagogik merupakan bagian yang tak terpisahkan dari empat kompetensi utama yang harus dimiliki seorang guru, yaitu kompetensi pedagogik, kepribadian, sosial, dan profesional (Sulfemi,2017;2). Guru adalah pendidik yang berkembang, tugasnya sebagai guru mengharuskan dia belajar sepanjang hayat, karena hal tersebut sejalan dengan tututan zaman. Sebagai pendidik upaya guru dalam membelajarkan siswa meliputi ha-hal berikut:

1) Menyelenggarakan tertib belajar disekolah

2) Membina disiplin belajar dalam tiap kesempatan, seperti pemanfaatan waktu

3) Membina belajar tertib pergaul

4) Membina belajar tertib lingkungan sekolah (Sulfemi, 2019;5).

Selain kemampuan pedagogik ada beberapa kompetensi yang harus dipenuhi, yaitu kompetensi kepribadian sekurang-kurangnya mencakup kepribadian yang diantaranya :

1) Beriman dan takwa

2) Berakhlak mulia

3) Arif dan bijaksana

4) Demokratis

5) Mantap

6) Berwibawa

7) Stabil

8) Dewasa

9) Jujur

10) Sportif

11) Menjadi teladan bagi peserta didik dan masyarakat

12) Secara objektif mengevaluasi kinerja sendiri

13) Mengembangkan diri secara mandiri dan berkelanjutan

Adapun kompetensi sosial merupakan kemampuan guru sebagai bagian dari masyarakat, yang sekurang-kurangnya meliputi kompetensi untuk :

1) Berkomunikasi lisan, tulis, isyarat secara santun

2) Menggunakan teknologi komunikasi dan informasi secara fungsional

3) Beragaul secara efektif dengan peserta didik, sesama pendidik, tenaga kependidikan, pimpinan satuan pendidikan, orangtua atau wali murid 
4) Bergaul secara umum dengan masyarakat

Kompetensi profesional merupakan kemampuan guru dalam menguasai pengetahuan bidanga ilmu pengetahuan, teknologi, atau seni dan budaya yang diampunya yang meliputi penguasaan :

1) Materi pelajaran secara luas dan mendalam sesuai dengan standar isi program satuan pendidikan, mata pelajaran, dan kelompok mata pelajaran yang akan diampu

2) Konsep dan metode sisiplin keilmuan, teknologi, atau seni yang relevsn, yang secara konseptual menaungi atau koheren dengan program satuan pendidikan, mata pelajaran, atau kelompok mata pelajaran yang akan diampu.

\section{Peran Guru Sebagai Insan Multidimensi}

Di dalam pembelajaran, apakah itu pmebelajaran konvensional yang berorientasi teacher-centered maupun dalam pembelajaran yang berorientasi student-centered, sesungguhnya peran guru itu unik dan boleh dikatakan tidak tergantikan. Guru yang bersandangan fasilitator dalam membantu siswa, toh tetap dituntut perannya sebagai guru, sebagai orang dewasa yang karena kompetensinya siap membantu siswa beranjak menuju struktur kognitif yang leih kompleks dalam zona perkembangan terdekatnya. Agar proses pembelajaran dapat dilaksanakan secara efektif dan efisien, serta mencapai hasil yang diharapkan, diperlukan kegiatan manajemen sistem pembelajaran, sebagai keseluruhan proses untuk melaksanakan kegiatan pembelajaran secara efektif dan efisisen (Sulfemi,2017;4-5).

Terkait dengan sejumlah sandangan yang mau tidak mau harus diterima guru, sebagai guru profesional yang efektif dan guru yang unggul (the excellence teacher) banyak teori yang telah dipaparkan oleh pakar pendidikan. Dalam proses belajarmengajar, guru mempunyai tugas untuk mendorong, membimbing, dan memberi fasilitas belajar bagi siswa untuk mencapai tujuan. Guru mempunyai tanggung jawab untuk melihat segala sesuatu yang terjadi dalam kelas untuk membantu proses perkembangan siswa. Demikian dalam proses belajar-mengajar guru tidak terbatas sebagai penyampai ilmu pengetahuan akan tetapi lebih dari itu, ia bertanggung jawab akan keseluruh perkembangan kepribadian siswa. Ia harus menciptakan proses belajar sedemikian rupa sehingga dapat merangsang siswa untuk belajar secara aktif dan dinamis dalam memenuhi kebutuhan dan menciptakan tujuan (Sulfemi, 2019;2-3). Guru sebagai sseseorang yang cukup kompeten ditanya apa tugas pokok seorang guru, maka secara spontan ia akan menjawab, ya mendidik dan mengajar. Mendidik bukanlah tugas sederhana, pendidik yang sesungguhnya harus mampu membawa orang lain 
beranjak dari kegelapan menuju suatu pencerahan yang terang benderanag. Inilah sandangan pokok seorang guru. Istilah guru dengan demikian memiliki konotasi yang aung. Dalam agama, salah satu fungsi rabb, Tuhan adalah guru. Sehingga guru sebagai guru sebenarnya merupakan insan kamil, manusia unggul yang mampu beradaptasi dan melakukan transformasi diri dan senantiasa bergelut dari suatu perbaikan ke perbaikan yang lain. dalam istilah filsafat manusia, manusia yang demikian itu disebut homo concors, manusia adaptif dan transformatif.

Sebagai pengajar sebenarnya rumusannya amat sesderhana, ia membantu dan membimbing siswa yang sedang berkembang untuk belajar, belajar tentang sesutu yang belum diketahuinya. Pengajar yang unggul yang sesunggguhnya akan selalu dikenang siswanya, karena dia demikian terampil menyederhanakan suatu masalah yang pelik dan rumit, kemudian menjelaskan dengan gamblang prinsip-prinsip yang terkait dengan penyelesaian maslah tersebut. Selanjutnya guru sebagai pengajar yang unggul membantu para siswa pembelajar untuk mengembangkan cara-cara belajarnya sendiri. Pada kenyataannya dengan pilihan model pembelajaran apa pun selalu ada ruang bagi para guru menyelesaikan tugas-tugas dan menilai hasilnya. Menerangkan (explaining) dengan gamblang prinsip-prinsip yang terkait dengan penyelesaian masalah tersebut. Selanjutnya guru sebagai pengajar yang uggul membantu para siswa pembelajar untuk mengembangkan cara-cara belajarnya sendiri. Ada sejumlah tips yang perlu dilaksanakan seorang guru sebagai guru, antara lain :

a) Berilah contoh, kontekstualkan pembelajaran

b) Nyatakan sesuatu yang di pelajari dalam istilah-istilah yang sederhana

c) Uraikan masalah menjadi bagian-bagian yang sederhana

d) Ajukan pertanyaan-[ertanyaan yang bermakna

e) Beri inspirasi untuk meningkatkan keprcayaan diri siswa.

f) Seediakan fasilitas bagi kemungkinan munculnya berbagai cara pandang

g) Sajikan pembelajaran yang menyenangkan dan dinamis

1. Guru Sebagai Teladan

Guru adalah model mental yang hidup bagi siswa. Kita ingat pemeo guru, segai digugu lan ditiru (ditaati dan ditiru), guru adalah uswah hasanah (teladan yang baik). Sandangan ini memang cukup berat bagi guru, tetapi tek terelakkan, apalagi pada tingkat pendidikan dasar. Bagi anak TK dan SD guru merupakan segala-segalanya. Alhasil seringkali siswa-siswa pemula (novice learner) tersebut memandang apa saja yang dikatakan gurunya sebagai yang benar, peran guru yaitu sentral, sehingga sekali guru membuat kesalahan, kesalahan semacam ini akan lama dikenang siswa. 
Kualitas dan kekuatan dari teladan seorang guru berkaitan erat dengan karakter dan efektivitas guru. Makin efektif seorang guru maka makin tinggi pula potensi dan kekuatannya sebagai teladan. Kualitas semacam ini akan membuatnya terampil di dalam pembelajaran, sehingga mapu imajinasi, kegairahan, makna bagi pembelajaran dan pada gilirannya memberikan satu energi kepada guru sebagai teldan. Teladan yag efektif akan mampu memberi semangat dan keberanian para siswa untuk belajar. Agar efektif sebagai teladan, ada sejumlah faktor yang harus diperhatikan guru :

a) Sikap dasar, yaitu sikap guru dalam menyelesaikan masalah yang penting dan berdampak kepada kesuksesan, kegagalan, pembelajaran dan lain-lain

b) Kecakapan berbicara, termasuk penggunaan intonasi dan pemilihan kata yang tepat

c) Kebiasaan kerja, termasuk konsistensinya, kerapian dan kedisiplinan

d) Pakaian, menampilkan ciri kepribadian

e) Model berpikir, terkait dengan cara pikiran bekerja

2. Guru Sebagai Pembaru

Tugas guru untuk menerjemahkan sekaligus membahasakan berbagai karya IPTEK itu kepada murid dengan gaya bahasa yang baru yang mudah dipahami oleh siswanya. Inilah makna guru sebagai pembaharu, dia harus memperbarui seluruh "bahasa" dari karya agung manusia itu sehingga dapat dipahami lebih mudah oleh muridnya. Sekali lagi perlu ditegaskan bahwa tugas guru adalah menyampaikan kekyaan karya agung, warisan budaya dan hikmah kebijakan manusia di masa lalu dengan suatu bahasa, dan istilah yang modern, istilah yang mudah dipahami oleh para siswa pada saat ini. Ini terkait dengan pilihan metode dan strategi pembelajaran oleh guru. Dengan demikian, guru agar dapat menyesuaikan diri dengan perkembangan serta tidak jauh dari realistis kehidupan siswa, harus selalu memodernisasi, memperbarui gaya serta cara berpikirnya, memperbarui gaya mengajarnya.

Guru diharapkan memodifikasi rancangan dan pelaksanaan pengajaran, berperan aktif serta menempatkan kedudukannya sebagai tenaga profesional, sesuai dengan tuntutan masyarakat yang semakin berkembang untuk meningkatkan hasil belajar peserta didik sesuai dengan harapan (Sulfemi, 2019;18-20).

3. Guru Sebagai Pemandu 
Pembelajaran adlah suatu wisata, wisata yang berjalan dari suatu pos pengetahuan satu menuju pos pengetahuan lain, dari suatu kompetensi dasar lain. Di dalam setiap pos, siswa akan menjumpai sejumlah kekayaan pengetahuan dan hikmah dari pembelajaran. Siswa adalah para pelancongnya dan guru adalah pemandunya. Pemandu akan menjelaskan, memberikan eksentuasi tentang ciriciri pokok setiap pos pengetahuan sampai kepada tujuan akhir, yaitu diselesaikannya tujuan pembelajaran sesuai dengan ancangan kurikulum. Cara guru memandu wisata dan cara mengajar adalah suatu cara pandang atau pemikiran untuk membuat pembelajaran menjadi tampa berbeda setiaphari, karena setiap pos pengetahuan memiliki ciri-ciri keindahannya. Metode demonstrasi adalah metode yang digunakan untuk memperlihatkan suatu proses atau cara kerja suatu benda yang berkenaan dengan bahan bahan pelajaran (Sulfemi, 2018;152).

Ada sejumlah tips yang harus dilakukan guru dalam memandu wisata pembelajaran, yaitu :

a) Selalu merencanakan tujuan program pembelajaran dengan baik

b) Harus berupaya agar siswa dapat melaksanakan wisata pembelajaran dengan baik

c) Buatlah wisata pembelajaran menjadi penuh makna

d) Penilaian harus bersifat autentik

4. Guru Sebagai Pelaksana Tugas Rutin

Mari kita lihat apa saja tugas rutin guru yang tak terelakkan, baik yang selalu dihadapi oleh guru TK, SD, SMP, sampai guru sekolah menengah pada umumnya:

a) Merencanakan pembelajaran, menyiapkan silabus dan menyusun RP (Rancangan Pembelajaran)

b) Tidak terlambat masuk kelas dan tidak terlambat mengahdiri rapat guru

c) Menulis catatan dan laporan dengan seksama dan hati-hati

d) Membaca, memberikan komentar, menilai, dan mengembalikan tugas-tugas siswa

e) Menetapkan batas waktu bagi tugas-tugas murid

f) Merencanakan pertemuan dengan orang tua atau dengan siswa di luar jam pembelajaran

Tugas-tugas rutin semacam itu sering menimbulkan kejemuan kepada guru sehingga acap kali para guru tergoda untuk memperoleh kebebasan dari tugas rutin itu. Satu hal yang penting dicamkan, iklim belajar yang amat diperlukan bagi tercapainya situasi pembelajaran produktif dan efektif amat ditentukan oleh hadirnya rasa tenteram dan kesenangan, konsistensi untuk mengerjakan tugas- 
tugas rutin semacam itu. Tugas rutin yang dikerjakan dan diselesaikan dengan baik akan menghasilkan suatu tatanan dan keyakinan yang penting bagi timbulnya karya kreatif.

5. Guru Sebagai Peneliti

Guru adalah seorang peneliti, pencari tahu segala sesuatu. Sebagai manusia sudah menjadi fitrah bawaannya bahwa ia dilahirkan penuh oleh semangat kuriositas, rasa ingin tahu. Sementara itu, karena ia dituntut untuk memberitahukan, menginformasikan pengetahuannya kepada para siswanya, maka usaha pencarian tahu, sebagai peneliti akan merupakan upaya pencarian tahu terhadap kebenaran yang akan merupakan upaya pencarian tahu terhdap kebenaran yang tidak terbatas, tidak pernah berakhir sepanjang kehidupannya.

Guru sebgai seorang peneliti adalah peneliti sejati. Ia memiliki dan selalu meemelihara semangat inkuiri yang tidak pernah padam. Ia tidak sekedar menyatakan bahwa ia sedang mencari tahu sesuatu, tetapi ia memang benar-benar sedang mencari tahu sesuatu. Selayaknya memang, bahwa keinginan para guruuntuk mengetahui dna memahami sesuatu itu demikian besar, karena hal ini merupakan suatu kualitas yang membuktikan cinta mereka yang besar pula terhadap pengetahuan.

6. Guru Sebagai Pembongkar Kemah

Guru adalah seorang pembongkar kemah, membongkar kemah adalah suatu idiom. Makna sesungguhnya ialah suatu pola pikir atau sikap mental yang nonsistematis, berani mengambil risiko atau meninggalkan cara berpikir dan sikap pandang lama yang sudah mapan. Kemudian menggantinya dengan cara berpikir dan sikap pandang dan cara hidup yang baru, yang belum mapan dan panuh tantangan, menuju suatu pertumbuhan dan perkembangan pribadi. Inilah sesungguhnya konsep unlearn, meninggalkan hikmah pembelajaran terdahulu, untuk kemudia relearn, belajar lagi dengan sikap pandang dan cara berpikir baru untuk memperoleh hikmah pembelajaran yang baru pula.

Dalam hal ini tugas berat guru adalah harus memahami berbagai sikap pandang siswa yang ternyata menghambatnya untuk mencapai kemajuan, di sisi lain juga harus mengetahui berbagai kekuatan sswa yang harus dikembangkan, sesuai dengan derajat perkembangan mental, sosial, dan moral siswa. Pendidikan dan pembelajaran yang baik harus mampu membantu pembelajar menyesuaikan berbagai masalahnya saat ini, dengan membongkar berbagai cara pandang yang lama yang menjadi hambatan, kemudian menggunkan pengalaman belajar yang 
diperolehnya untuk mengantisipasi berbagai masalah yang akan dijumpainya di masa depan.

\section{Kesimpulan}

Guru adalah orang yang mempunya peranan penting dalam menumbuhkan dan mengembangkan potensi yang dimiliki siswanya. Peran guru disekolah sangatlah strategis, oleh karena itu guru dituntut untuk memiliki empat kompetensi sesuai standard kompetensi yang tertuang dalam Undang-undang Nomor 14 Tahun 2005 tentang Guru dan Dosen pada Bab IV Pasal 10 ayat (1), yang menyatakan bahwa "Kompetensi guru meliputi kompetensi pedagogik, kompetensi kepribadian, kompetensi sosial, dan kompetensi profesional yang diperoleh melalui pendidikan profesi.

Guru merupakan faktor yang sangat dominan dan penting dalam pendidikan formal pada umumnya, karena bagi peserta didik guru sering dijadikan tokoh teladan bahkan menjadi tokoh identifikasi diri. Oleh karena itu guru seyogyanya memiliki perilaku dan kompetensi yang memadai untuk mengembangkan peserta didik secara utuh. Untuk menguasai berbagai hal terutama kompetensi kepribadian, sosial dan profesional. 


\section{E. Daftar Pustaka}

Sulfemi, Wahyu Bagja. (2016). Hubungan Persepsi Peserta Didik Tentang Kompetensi Guru Mata Pelajaran Sejarah dengan Hasil Belajar Mata Pelajaran Sejarah di Kelas X SMA Negeri 1 Pamijahan Kabupaten Bogor. Fascho : Kajian Pendidikan dan Sosial Kemasyarakatan. 5 (2), 52-70.

Sulfemi, Wahyu Bagja dan Lestari, Ayu Hopilatul. (2017). Korelasi Kompetensi Pedagogik Guru dengan Prestasi Belajar Mata Pelajaran IPS Di SMP Muhammadiyah Pamijahan Kabupaten Bogor. Edutecno. 16 (1), 1-16.

Sulfemi, Wahyu Bagja dan Supriyadi, Dede. (2018). Pengaruh Kemampuan Pedagogik Guru dengan Hasil Belajar IPS. Edutecno 17 (1), 1-10.

Sulfemi, W. B., \& Nurhasanah. (2018). Penggunaan Metode Demontrasi Dan Media Audio Visual Dalam Meningkatkan Hasil Belajar Peserta Didik Mata Pelajaran IPS. Pendas Mahakam: Jurnal Pendidikan Dasar, 3(2), 151-158.

Arsyad, A. (2019). Korelasi Penguasaan Materi Pembelajaran Oleh Guru Dengan Motivasi Belajar Siswa Mata Pelajaran Administrasi Perkantoran di SMK Pelita Bogor.

Suryono, Hariyanto.(2011).Belajar dan Pembelajaran.Bandung.PT Remaja Rosdakarya 


\section{F. Soal}

\section{Pilihan Ganda}

1. Kompetensi pedagogik merupakan bagian yang tak terpisahkan dari empat kompetensi utama yang harus dimiliki seorang guru yaitu, kecuali ....
a. Kepribadian
c. Ramah
b. Sosial
d. Profesional

2. Contoh dari kemampuan kepribadian, yaitu ....
a. Membuat RPP
c. Berakhlak mulia
b. Membuat silabus
d. Mengevaluasi

3. Kompetensi sosial yang harus dimiliki guru sebagai berikut, kecuali ....
a. Berkomunikasi baik
c. Berwibawa
b. Bergaul secara efektif
d. Bersosialisasi

4. Sebagai pengajar, rumusannya amat sederhana. Yaitu membantu dan membimbing siswa untuk ....
a. Mandiri
c. Belajar
b. Bertanggung jawab
d. Berbudi pekerti

5. Kualitas dan kekuatan dari teladan seorang guru berkaitan erat dengan ....
a. Karakter dan sikap
c. Karakter dan efektivitas
b. Sikap dan efektivitas
d. Wibawa dan efektivitas

6. Sikap dasar, yaitu sikap guru dalam menjelaskan masalah yang penting dan berdampak kepada, kecuali ....
a. Kesuksesan
c. Motivasi
b. Kegagalan
d. Pembelajaran

7. Bentuk peran guru sebagai insan multidimensi diantaranya, kecuali ....
a. Sebagai peneliti
c. Sebagai visioner
b. Sebagai pembongkar kemah
d. Sebagai pemandu

8. Pencari tahu segala sesuatu yaitu peran guru sebagai ....
a. Pembicara
c. Peneliti
b. Pemandu
d. Teladan

9. Agar efektif sebagai teladan, ada beberapa faktor yang diperhatikan guru adalah, kecuali ....
a. Sikap dasar
c. Berwibawa
b. Kecakapan berbicara
d. Pakaian 
10. Guru diharapkan memodifikasi rancangan dan pelaksanaan pengajaran adalah salah satu peran guru sebagai ....
a. Peneliti
c. Pembaru
b. Pemandu
d. Pelaksana tugas rutin

\section{ESSAY}

1. Sebutkan kompetensi pedagogik yang merupakan bagian tak terpisahkan dari empat kompetensi utaman!

2. Berikan contoh kompetensi kepribadian! Minimal 5

3. Sebutkan bentuk-bentuk peran guru sebagai insan multidimensi!

4. Apa yang dimaksud dengan guru sebagai peran peneliti?

5. Bagaimana kerja guru sebagai yang berperan guru pembaru?

\section{G. Kunci Jawaban}

Pilihan Ganda

$\begin{array}{ll}\text { 1. } & \mathrm{C} \\ \text { 2. } & \mathrm{C} \\ \text { 3. } & \mathrm{C} \\ \text { 4. } & \mathrm{C} \\ \text { 5. } & \mathrm{C} \\ \text { 6. } & \mathrm{C} \\ \text { 7. } & \mathrm{C} \\ \text { 8. } & \mathrm{C} \\ \text { 9. } & \mathrm{C} \\ \text { 10. } & \mathrm{C}\end{array}$




\section{Essay}

1. Kepribadian, sosial, profesional, pedagogik

2. Beriman dan takwa, Berakhlak mulia, Arif dan bijaksana, Demokratis, Berwibawa

3. Guru sebagai peneliti, guru sebagai pemandu, guru sebagai pembongkar kemah, guru sebagai pembaru, guru sebagai pelaksana tugas rutin

4. Guru adalah seorang peneliti, pencari tahu segala sesuatu. Sebagai manusia sudah menjadi fitrah bawaannya bahwa ia dilahirkan penuh oleh semangat kuriositas, rasa ingin tahu.

5. Guru diharapkan memodifikasi rancangan dan pelaksanaan pengajaran, berperan aktif serta menempatkan kedudukannya sebagai tenaga profesional, sesuai dengan tuntutan masyarakat yang semakin berkembang untuk meningkatkan hasil belajar peserta didik sesuai dengan harapan 
